\title{
Analisis Pentakostalisme Terhadap Markan Ending
}

\author{
Valentino Wariki \\ Sekolah Tinggi Teologi Bethel Indonesia \\ valentinowariky@gmail.com
}

\begin{abstract}
Abstrak
Permasalahan tekstual yang terdapat pada Markan Ending tidak memengaruhi kaum Pentakostal dalam kesetiaannya terhadap teks ini. Kelompok Pentakostal merupakan komunitas yang karakter gerejanya lekat dengan karunia Roh. Markan Ending telah menjadi bagian dari Kitab Suci yang demikian melekat pada Pentakostalisme. Sejarah menunjukkan bahwa persebaran dua Markan Ending yaitu Abrupt Ending dan Long Ending terjadi secara natural dan diterima baik oleh banyak kelompok gereja. Historitas kedua Markan Ending yang telah ada sejak masa awal gereja menjadi bukti bahwa teks ini tidak saling berkonfrontasi. Melalui Pentecostal Reading maka terbuka cara yang fair dalam melihat kedua penutup Injil Markus ini sebagai bagian sakral Kitab Suci yang tak terpisahkan. Kisah Para Rasul 2 yang menjadi ideologi dasar Pentakostalisme menjadi penghubung dengan bagian lain dari teks Kitab Suci guna mengungkap relevansi dogmatis dari ajaran yang terdapat dalam Markan Ending.
\end{abstract}

Kata Kunci: Markan Ending, Abrupt Ending, Long Ending, dan Analisis Pentakostalisme

\section{Pendahuluan}

Fakta akan adanya komunitas setia yang masih percaya kepada doktrin yang terkandung dalam perikop ini pun menjadi alat argumentasi baru dalam mempertahankan Long Ending sebagai bagian dari Kitab Suci. Ketidakberadaan Long Ending di naskah-naskah tertua dan terbaik tidak serta merta membuat statusnya sebagai bagian dari Kitab Suci hilang begitu saja. Dibutuhkan penelaahan yang komprehensif terhadap isu tekstual ini.

Markan Ending tidak hanya dapat dilihat dari isu tekstual. Bagian penutup dari Injil Markus juga memunculkan isu doktrinal yang menjadi bagian penting dalam kehidupan bergereja khususnya bagi kalangan Pentakostal. Jika isu tekstual dapat dicermati dari perspektif metode hermeneutik maka isu doktrinal dapat dijawab melalui argumentasi-argumentasi dogmatis sejauh itu relevan dan konsisten dengan semangat dan natur Pentakostalisme. Tentu dalam menjawab area dogmatis, prinsip pokok dari metode hermeneutik tidak lantas ditinggalkan begitu saja.

\section{Metode Penelitian}

Penelitian ini merupakan penelitian biblika yang bertujuan untuk melakukan tafsir melalui proses hermeneutik dan eksegesi. Penelitian ini hendak menggali beberapa teks di Alkitab yang akan ditafsirkan. Hasil tafsiran kemudian 
dikaitkan dengan teori-teori maupun pustaka-pustaka yang relevan. Kaitan antara hasil tafsiran dengan teori-teori kemudian dianalisi, sehingga diperoleh simpulan mengenai tujuan penelitian ini, yaitu hasil analisis pentakostalisme terhadap markan ending.

\section{Hasil Penelitian dan Pembahasan}

Bukti Eksternal Abrupt Ending dan Long Ending sebagai Bukti Historis Eksistensi Diversitas Markan Ending pada Masa Awal Kekristenan

Bukti eksternal menjadi suatu media yang signifikan dalam meneliti eksistensi teks tertentu berkenaan dengan varianvariannya. Sebagaimana telah disampaikan di bagian pendahuluan bahwa Markan Ending setidaknya terdiri atas empat penutup yang berbeda. Masing-masing penutup memiliki karakteristik serta didukung oleh varian yang berbeda.

Tidak hanya varian dalam bahasa Yunaninya saja, terjemahan atau versiversi kuno teks juga kesaksian para bapa gereja menjadi suatu pertimbangan yang patut dikedepankan. Ketiganya menjadi standar acuan di bidang kritik teks dalam menelaah otentisitas suatu teks.

Karenanya pada bagian ini akan dipaparkan pembahasan mengenai bukti eksternal Abrupt Ending dan Long Ending. Tujuan pokok dari pembahasan pada bagian ini bukan untuk mendukung Long
Ending sebagai bagian yang otentik dari Markan Ending. Melainkan lebih untuk menunjukkan bagaimana historitas kedua Markan Ending yang telah ada sejak masa awal gereja. Dan tidak ada konfrontasi serius di antara keduanya.

\section{Abrupt Ending}

Abrupt Ending merupakan Markan Ending yang ditutup oleh evfobou/nto ga,r. Disebut Abrupt Ending dikarenakan penutup Injil Markus ini dirasa janggal. Janggal karena Injil yang seharusnya merupakan kabar sukacita berakhir dengan ketakutan para murid Tuhan Yesus.

Beberapa bukti eksternal menunjukkan keberadaan AE sebagai Markan Ending. Bukti-bukti terbaik dari manuskrip Perjanjian Baru Yunani seperti kodeks $¥$ dan kodeks B mengukuhkan Markan Ending ini. Meskipun hanya didukung dua unsial utama yaitu Sinaitikus dan Vatikanus, kenyataannya dua unsial itu telah diakui secara luas sebagai dua manuskrip Perjanjian Baru Yunani yang terbaik.

Terjemahan lain seperti Latin Kuno, Sinaitik Siria, Koptik, Armenia, dan Georgia memuat penutup Injil Markus hanya sampai di ayat 8. Dari dua terjemahan tersebut, edisi Latin Kuno dan Sinaitik Siria merupakan edisi yang tertua. Usia manuskrip yang memuat terjemahan 
Markan Ending di dua terjemahan ini berkisar di abad ke-2 dan ke-3 M.

Mengacu kepada kutipan Bapa Gereja, maka setidaknya ada beberapa nama berpengaruh yang hanya mengenal dan memercayai Markan Ending berakhir di ayat delapan. Klemen dari Aleksandria, Origen, dan Eusebius merupakan kelompok yang mengenal AE sebagai Markan Ending yang autentik.

\section{Long Ending}

Long Ending merupakan Markan Ending tradisional yang melanjutkan narasinya sampai di ayat 20. Sama halnya dengan Abrupt Ending, Long Ending juga memiliki bukti-bukti eksternal yang tidak kalah penting. Setidaknya 3 unsial utama Yunani menjadi saksi keberadaan penutup ini yaitu Aleksandrinus, Bezae, dan Washingtonianus.

Demikian pula dengan dukungan dari terjemahan Lain. Siria versi Peshitta, Philoxenian, Harklean dan Siria Palestina memasukkan Long Ending sebagai Markan Ending mereka. Salah satu terjemahan Latin yang berpengaruh yaitu Vulgata turut menyertakan Long Ending di akhir Injil Markus. Kemudian terjemahan Gothik melalui kodeks Argentusnya menutup Injil Markus dengan Long Ending.

Salah satu kutipan Bapa Gereja yang berpengaruh terhadap eksistensi Long Ending sebagai penutup Injil Markus terpelihara melalui tulisan Eusebius. Menurut catatan Eusebius dalam Ecclesiastical History tentang seseorang bernama Justus Barsabbas dinyatakan bahwa :

kai. pa,lin eteron paradoxon peri Iouston ton epiklhqenta Barsabban gegonojÃ wj dhlhthrion farmakon empiontoj kai. mhden ahdej dia thn tou kuriou carin upomeinantoj) Karena ia menceritakan kebangkitan dari kematian dalam masanya, lalu suatu paradoks lain tentang Justus seseorang yang dipanggil Barsabbas, yang telah minum racun mematikan lalu melalui anugerah Tuhan, ia tidak menderita apapun juga.

Kutipan Eusebius dari Papias ini memiliki keserupaan dengan ayat 18 dari LE yang bunyinya :

kai. evn tai/j cersi.n o;feij avrou/sin ka'n qana,simo,n ti pi,wsin ouv mh. auvtou.j bla,yh|(evpi. avrrw,stouj cei/raj evpiqh,sousin kai. kalw/j e[xousin $\AA$ dan mereka akan memegang ular dan jika mereka minum racun mematikan mereka tidak akan celaka, mereka akan meletakkan tangannya ke atas orang sakit dan mereka akan sembuh.

Yustinus Martir, Tatian, dan Irenaeus merupakan kelompok yang sama dengan Papias yang meyakini bahwa Injil Markus ditutup oleh Long Ending. 


\section{Pentecostal Reading}

Kenneth J. Archer

mengungkapkan suatu perbedaan yang signifikan antara kaum Protestan Klasik dan kaum Fundamentalis dengan kaum Pentakostal dalam pembacaan Kitab Suci. Menurutnya kaum Protestan Klasik dan kaum Fundamentalis membaca Kitab Suci sebagai dokumen penyataan yang diinspirasikan di masa lalu, sementara kaum Pentakostal membaca Kitab Suci sebagai cerita yang diinspirasikan di masa kini. Mereka membaca Kitab Suci secara literal, meruntuhkan jarak antara konteks origin dari Kitab Suci dan konteks pembaca (Martin, 2013).

Kaum Pentakostal meyakini bahwa apa yang terjadi di dalam Kitab Suci, dapat terjadi lagi (Archer, 2004). Karenanya di dalam memandang teks Kitab Suci yang merupakan karya Roh Kudus, metode Pentakostal ini berusaha menempatkan dirinya sebagai suatu jembatan antara pembaca teks di masa kuno dengan pembaca teks kontemporer (Vondey, 2013). Kaum Pentakostal memandang inspirasi Kitab Suci sebagai inspirasi yang tidak terbatas oleh waktu.

Kaum Pentakostal juga meyakini bahwa Kitab Suci secara inheren memiliki kemampuan untuk berbicara dengan penuh makna di dalam latar sosial yang berbeda daripada latar dimana Kitab Suci itu berasal (Archer, 2004). Kitab Suci di dalam pandangan kaum Pentakostal tidak hanya dapat dimaknai di satu wilayah geografis saja, namun lintas geografis.

Oleh karena dua pandangan dasar inilah sehingga dalam memandang karuniakarunia yang ada di dalam Kitab Suci, kaum Pentakostal tidak melihatnya sebagai suatu fenomena yang hanya terjadi di masa lalu dan di satu tempat saja, melainkan memandangnya sebagai suatu bagian dari pengalaman pasca Pentakosta. Pengalaman yang dapat terjadi di masa sekarangj juga (Dayton, 1987). Pembaca Pentakostal bertemu dan mengalami Allah melalui teks Kitab Suci. Pertemuan itu terjadi generasi demi generasi.

\section{Kisah Para Rasul 2 sebagai ideologi Pentakostalisme}

Secara doktrinal, Long Ending memiliki posisi yang signifikan terutama bagi kaum Pentakostal. Terutama ketika merujuk kepada ayat 17 dan 18 . Ayat 17 dan 18 merupakan bagian dari Long Ending yang membahas karunia yang menyertai orangorang percaya. Berbicara mengenai karunia maka ada beberapa bagian teks dalam Kitab Suci yang saling terkait antara satu dan lainnya. Salah satunya terdapat di dalam narasi Kisah Para Rasul 2. Bagian ini merupakan bagian yang penting bagi kelompok Pentakostal, karena dari teks itulah mereka dinamakan (Noel, 1970). Wolfgang Vondey menyatakan bahwa 
catatan-catatan di sekitar hari Pentakosta jelas disarankan bagi bacaan kaum Pentakostal modern dan inilah yang disebut sebagai hermeneutik (Vondey, 2013). Perkataan yang disampaikan Petrus menggambarkan bahwa peristiwa di hari Pentakosta tersebut merupakan pemenuhan dari kata-kata profetik nabi Yoel. Dan manifestasi karunia-karunia Roh sebagai dampak dari pencurahan Roh pada masa itu oleh kaum Pentakostal dipandang dapat terus berlangsung di tengah-tengah mereka pada masa kini. Karenanya kaum Pentakostal menegakkan narasi historikal Kisah Para Rasul sebagai catatan teologikal normatif dari kehidupan kekristenan yang dipenuhi oleh Roh Kudus (Vondey, 2013). Terutama catatan di Kisah Para Rasul 2, suatu catatan yang mengawali narasi pneumatologinya Lukas.

Kisah Para Rasul 2 menceritakan saat dimana Roh Kudus dicurahkan pada hari Pentakosta (Fernando, 1998). Pada saat itu para murid dipenuhi oleh Roh Kudus dengan disertai tanda-tanda dari langit yaitu suara seperti angin ribut dan lidahlidah seperti nyala api (Gaebelein, 1981). Adegan setelah tanda-tanda dari langit itu adalah para murid mengalami kepenuhan Roh Kudus (evplh,sqhsan pa,ntej pneu,matoj a'gi,ou). Mereka kemudian berkata-kata dalam bahasa yang lain (lalei/n e`te,raij glw,ssaij) (Barnes, 1983).
Aktifitas berkata-kata dalam bahasa yang lain merupakan bagian dari suatu karunia. Dalam peristiwa yang dicatat Lukas dalam Kisah Para Rasul 2 karunia ini dialami oleh para murid (Lenski, 1946). Karunia yang diberikan kepada para murid itu bukannya tanpa tujuan. Pada ayat 11 dinyatakan bahwa karunia yang diperkatakan para murid bertujuan untuk memuliakan Allah (avkou,omen lalou,ntwn auvtw/n tai $/ \mathrm{j}$ h'mete,raij glw,ssaij ta. megalei/a tou/ qeou/) (Stronstad, 1984). Jadi karunia ini bukanlah tanda yang sembarangan, melainkan tanda dimana Tuhan memperlengkapi para pelayan-Nya dengan tujuan memuliakan-Nya dalam bahasa yang lain (Keener, 2009). Karunia diberikan untuk dikembalikan bagi kemuliaan Allah. Kemuliaan yang dinyatakan melalui keragaman berbahasa. Kisah Para Rasul 2 menjadi simbol dimana semua suku bangsa diajak untuk memuliakan Allah (Macchia, 2005). Dan karunia ini menjadi sarana bagi pengejawantahan maksud Allah.

Tentu momen langka ini akan menarik perhatian banyak orang kala itu. Keberadaan para peziarah yang diidentifikasikan oleh Lukas itu sebagai orang-orang yang berasal dari 15 macam bangsa menjadi saksi akan peristiwa fenomenal itu (Kisah Para Rasul 2:9-11). Peristiwa dimana para murid dan pengikut Kristus berbicara di dalam bahasa-bahasa 
ke-15 suku bangsa itu. Pastinya akan tercipta suatu kesan yang mendalam, manakala seseorang mendengar bahasanya diucapkan di negara atau kawasan lain (Brink, 1996). Ditambah mereka yang berbicara bahasa lain itu merupakan orangorang Galilea, yang dikenal memiliki keunikan di dalam berbicara (Stott, 1990). Di sini terlihat bagaimana cara Allah bekerja dengan menggunakan bahasa manusia sebagai sarana kerjanya. Allah menggunakan bahasa sebagai sarana unifikasi manusia di dalam rangka karya keselamatan. Makna karunia berbahasa lain yang ada di narasi Lukas ini erat kaitannya dengan rencana keselamatan Allah.

Karunia berbahasa dalam bahasa lain juga merupakan salah satu tanda (shmei/on) yang kelak akan disingkapkan. Sebagaimana pernyataan Petrus yang mengutip tulisan nabi Yoel bahwa Allah akan mengadakan tanda-tanda di bumi. Tanda-tanda yang dimaksud menjadi suatu konsekuensi dari dicurahkannya Roh Kudus pada masa itu. Suatu momen yang dinantikan para murid sekaligus merupakan janji yang diberikan Yesus sesaat sebelum kenaikan-Nya (Kisah Para Rasul 1:5).

Momen dicurahkannya Roh Kudus pada narasi yang dituliskan Lukas di bukunya yang kedua menjadi titik penting bagi doktrin Pentakostalisme (Conn, 1965).
Khususnya pada pasal 2 dari Kisah Para Rasul yang oleh orang Pentakostal sering kali dijadikan bukti mengenai keberadaan doktrin dibaptis dengan Roh Kudus (Bruner, 1970). Dibaptis dengan Roh adalah suatu kondisi dimana seseorang dipenuhi oleh Roh Kudus. Pengalaman dipenuhi oleh Roh merupakan inti dari teologi Pentakostalisme dan Kharismatik (Anderson, 2014). Tanda-tanda yang diperlihatkan Lukas melalui narasinya ini menjadi legalitas dari doktrin dibaptis dengan Roh Kudus. Dan dalam hal ini, berbicara dengan bahasa yang lain merupakan tanda dari baptisan Roh Kudus itu. Oleh orang Pentakostal mula-mula, bahasa lidah dipandang sebagai bukti dari baptisan Roh Kudus. Pandangan tersebut tetap dipertahankan oleh sebagian besar kaum Pentakostal masa kini.

\section{Data biblikal mengenai karunia Roh}

a. Yoel 2:28-30

Momen utama dari nubuat Yoel itu adalah saat dimana Allah akan mencurahkan Roh-Nya sendiri (yxiWrta, \%APv.a,). Roh yang dicurahkan merupakan wujud integrasi Allah dengan manusia (Jones, 2003). Roh itu diperuntukkan kepada semua manusia (rf'B'-1K'-1[;) (Keil dan Delitzsch, 1989). Petunjuk bahwa Allah memberikan Roh-Nya kepada seluruh manusia berasal dari kata 1Ko. Meski 1Ko 
memiliki makna "keseluruhan", namun bukan berarti secara mutlak berarti "keseluruhan". Baik eksistensi, keterlibatan serta natur daripada Roh Allah tidak memungkinkan bahwa seluruh manusia akan mengalami apa yang kelak dinubuatkan oleh Yoel. Akan lebih baik jika dimaknai bahwa Roh Allah akan tercurah kepada orangorang yang memenuhi kualifikasi dari Allah. Makna 1Ko disini akan lebih tepat dimengerti sebagai keleluasan Allah mencurahkan Roh-Nya tanpa memandang generasi, gender ataupun suku. Bahkan tidak membatasi Roh-Nya hanya kepada kaum Yahudi saja (Longman dan Dillard, 1994; Stott, 1992; Metzger, 1965).

Adapun dampak dari pencurahan Roh Kudus itu adalah akan diberikannya karunia-karunia. Setidaknya ada empat karunia yang dinubuatkan Yoel di dalam bagian teks ini. Keempat karunia itu adalah karunia bernubuat; karunia mendapat mimpi, karunia mendapat penglihatan-penglihatan, dan karunia mengadakan mujizat-mujizat. Dari keempat karunia tersebut, karunia mengadakan mujizat-mujizat merupakan karunia yang paralel dengan karunia yang dituliskan di dalam Long Ending.

b. 1 Korintus 12,14
Substansi Amanat Agung (Mk. 16:15) paralel dengan peristiwa-peristiwa yang melatarbelakangi fenomena karunia ini (Kis 2:4, 10:45). Kisah Para Rasul 2 menjadi bukti internal terkuat yang patut diajukan guna mengidentifkasi terminologi bahasa baru yang dimaksudkan penulis Long Ending. Letak persamaannya dengan karunia bahasa yang dimaksud oleh Paulus adalah karena kedua bahasa tersebut sama-sama bukanlah bahasa yang lazim digunakan oleh mereka yang mendapatkan karunia tersebut. Selain itu karunia berbahasa ini (baik yang ada di Long Ending, Kis. 2 dan surat 1 Kor 12,14) merupakan karunia yang berasal dari satu sumber yaitu Roh Kudus.

Selain karunia bahasa Roh, terdapat karunia lainnya yang paralel dengan karunia yang disebutkan di dalam Long Ending. Karunia tersebut adalah karunia menyembuhkan (1 Kor. 12:9). Kesamaan dari karunia-karunia tersebut adalah berasal dari janji Yesus tentang penyertaan Roh Kudus. Karunia-karunia tersebut diberikan melalui Roh Kudus. Karunia-karunia tersebut didapat bukan karena hasil upaya seorang individu, namun pemberian Roh itu sendiri.

\section{Penutup}

Komunitas Pentakostal mungkin menjadi salah satu komunitas orang 
percaya yang tetap memandang Long Ending sebagai suatu bagian yang kanonis dari Kitab Suci. Kandungan doktrin yang ada di dalamnya menjadi salah satu dasar argumentasi sehingga mengapa Long Ending tetap dapat diterima sebagai bagian dari teks Kitab Suci. Beberapa bagian lain dari Kitab Suci seperti Kisah Para Rasul 2, Yoel 2: 28-30, 1 Korintus 12, 14 menunjukkan bahwa Long Ending memiliki kesejajaran di dalam gagasan pokoknya.

Analisis Pentakostalisme memandang teks Kitab Suci sebagai hasil akhir dari para penulisnya. Ia tidak mermpermasalahkan peristiwa-peristiwa di masa lalu yang terjadi berkenaan dengan proses pembentukan tulisan tersebut. Ia juga tidak mempersoalkan siapa penulis dari masing-masing bagian Kitab Suci tersebut.

Melihat teks tersebut sebagai suatu bagian dari teks Kitab Suci merupakan tujuan utamanya. Prinsip dasar dari Analisis Pentakostalisme memungkinkan bagi orang percaya untuk tetap dapat melihat Long Ending sebagai bagian dari teks Kitab Suci yang kanonis dan teks tersebut tetap hidup di masa kini. Eksistensi dari diversitas Markan Ending menjadi suatu tantangan tekstual bagi dunia akademik teologi yang justru harus dicari solusinya, dan Analisis
Pentakostalisme menawarkan solusi tersebut.

\section{Daftar Pustaka}

Anderson, Allan Heaton, An Introduction to Pentecostalism, Cambridge: Cambridge University Press, 2014.

Archer, Kenneth J. A Pentecostal Hermeneutic for the Twenty-First Cntury: spirit,scripture and community, London: T\&T Clark International, 2004.

Barnes, Albert, Notes on the New Testament, Grand Rapids, Michigan: Baker Book House, 1983.

Brink, H.v.d. Tafsiran Alkitab:Kisah Para Rasul, Jakarta: BPK, 1996.

Bruner, Frederick Dale, $A$ Theology of the Holy Spirit: the Pentacostal experience and the new testament witness, Grand Rapids, Michigan: William B. Eerdmans, 1970 .

Carson, D.A. and Douglas J. Moo, $A n$ Introduction to the New Testament, Grand Rapids, Michigan: Zondervan, 2005.

Conn, Charles W. Acts of the Apostles, Cleveland, Tennessee: Pathway Press, 1965.

Cranfield, C.E.B, The Gospel According to Saint Mark, Cambridge: Cambridge University Press, 1959.

Dayton, Donald W. Theological Roots of Pentecostalism, New Jersey: Hendrickson Publishers, 1987. 
Drewes, B.F. Kisah Para Rasul, Jakarta: BPK, 2014. . Satu Injil Tiga Pekabar, Jakarta: BPK, 2009.

Dunn, James D.G. Baptism in the Holy Spirit, Philadelphia: The Westminster Press, 1970.

Fernando, Ajith, The NIV Application Commentary: Acts, Grand Rapids, Michigan: Zondervan, 1998.

Gaebelein, Frank E. (Ed.), The Expositor's Bible Commentary, Volume 9. The Acts of the Apostles, by Richard N. Longenecker, Grand Rapids, Michigan: Zondervan, 1981.

Hull, Robert F., The Story of the New Testament : movers, materials, motives, methods, and models, Atalanta: Society of Biblical Literature, 2010.

Jones, Arthur W. Walker, Hebrew for Biblical Interpretation, Atlanta: Society of Biblical Literature, 2003.

Keener, Craig S. Power of Pentecost: Luke's Missiology in Acts 1-2, AJPS $12: 1,2009$.

Keil, C.F. and F. Delitzsch, Commentary on the Old Testament in Ten Volumes, vol. X, "Joel". Dalam Minor Prophets, Peabody, Massachusetts: Hendrickson, 1989.

Kelhoffer, James A. Miracle and Mission: the authentication of missionaries and their message in the longer ending of Mark, Mohr Siebeck: Tubingen, 2000.
Komoszewski, J. Ed. M. James Sawyer, Daniel B. Wallace, Reinventing Jesus, Jakarta: Perkantas, 2011.

Lenski, R.C.H. The Interpretation of St. Mark's Gospel, Minneapolis, Minnesota: Augsburg Publishing House, 1946.

Longman III, Tremper and Raymond B. Dillard, An Introduction to the Old Testament, Grand Rapids, Michigan: Zondervan, 1994.

Frank D. Macchia, Groans too Deep for Wordsi: towards a theology pf tongues as initial evidence dalam www.apts.edu/ajps/98-2/98-2macchia.htm, 2005

Martin, Lee Roy, "Introduction to Pentecostal Biblical Hermeneutics" dalam Pentecostal Hermeneutic: a reader, Leiden, Boston: Brill, 2013.

Metzger, Bruce M. (Ed), The text of the fourth Gospel in the writings of Origen: The New Testament in the Greek fathers; no. 3, Atlanta, Georgia: Scholars Press, 1992.

The New Testamen, Its Background, Growth, and Content, Nashville, New York: Abingdon Press, 1965.

Noel, Bradley Truman. "Gordon Fee's Contribution to the Contemporary Pentecostalism's Theology of Baptism in the Holy Spirit", M.A. Thesis, Acadia University, 1998. 
Porter, Stanley E. Constantine Tischendorf

: the life and work of a 19th century bible hunter, London: Bloomsbury, 2015.

Stott, John R.W. The Message of Acts, Leicester: Inter-Varsity Press, 1990. - The Contemporary Christian, Leicester: Inter-Varsity Press, 1992

Stronstad, Roger, The Charismatic Theology of St. Luke, Peabody, Massachusetts: Hendrickson Publishers, 1984.

Vondey, Wolfgang, "A Passion for the Spirit: Amos Yong and the Theology and Science Dialogue", in The Theology of Amos Yong and the New face of Pentecostal Scholarship, Leiden: Brill, 2013.

Westcott, Brooke Foss and Fenton John Anthony Hort, The New Testament in the Original Greek, Cambridge and London: Macmillan and co, 1882. 